\title{
The immunomodulatory effects of TNF-a inhibitors on human Th17 cells via RORyt histone acetylation
}

\author{
Yi-Ching Lin ${ }^{1,2,3,4}$, Yu-Chih Lin ${ }^{5}$, Cheng-Chin Wu ${ }^{6}$, Ming-Yii Huang7, Wen-Chan \\ Tsai $^{2,6}$, Chih-Hsing Hung ${ }^{1,3,8,9,10}$, Po-Lin Kuo ${ }^{1,11}$ \\ ${ }^{1}$ Graduate Institute of Clinical Medicine, College of Medicine, Kaohsiung Medical University, Kaohsiung, Taiwan \\ ${ }^{2}$ Department of Laboratory Medicine, Kaohsiung Medical University Hospital, Kaohsiung Medical University, Kaohsiung, Taiwan \\ ${ }^{3}$ Department of Pediatrics, Kaohsiung Medical University Hospital, Kaohsiung Medical University, Kaohsiung, Taiwan \\ ${ }^{4}$ Department of Laboratory Medicine, Faculty of Medicine, College of Medicine, Kaohsiung Medical University, Kaohsiung, Taiwan \\ ${ }^{5}$ Division of General Internal Medicine, Department of Internal Medicine, Kaohsiung Medical University Hospital, Kaohsiung \\ Medical University, Kaohsiung, Taiwan \\ ${ }^{6}$ Division of Rheumatology, Department of Internal Medicine, Kaohsiung Medical University Hospital, Kaohsiung Medical \\ University, Kaohsiung, Taiwan \\ ${ }^{7}$ Department of Radiation Oncology, Kaohsiung Medical University Hospital, Kaohsiung Medical University, Kaohsiung, Taiwan \\ ${ }^{8}$ Department of Pediatrics, Kaohsiung Municipal Hsiao-Kang Hospital, Kaohsiung, Taiwan \\ ${ }^{9}$ Department of Pediatrics, Faculty of Medicine, College of Medicine, Kaohsiung Medical University, Kaohsiung, Taiwan \\ ${ }^{10}$ Research Center for Environmental Medicine, Kaohsiung Medical University, Kaohsiung, Taiwan \\ ${ }^{11}$ Institute of Medical Science and Technology, National Sun Yat-Sen University, Kaohsiung, Taiwan \\ Correspondence to: Wen-Chan Tsai, email: d740094@cc.kmu.edu.tw \\ Chih-Hsing Hung, email: pedhung@gmail.com \\ Po-Lin Kuo, email: kuopolin@seed.net.tw
}

Keywords: TNF-a, Th17, RORYt, histone acetylation, rheumatoid arthritis

Received: August 31, $2016 \quad$ Accepted: November 22, $2016 \quad$ Published: December 03, 2016

\section{ABSTRACT}

The presence of interleukin (IL)-17-related cytokines correlates with rheumatoid arthritis (RA) pathogenesis. Epigenetic modifications, including histone acetylation, regulate gene expression in RA pathogenesis. Tumour necrosis factor-alpha (TNF-a) inhibitors such as etanercept and adalimumab, represent a breakthrough in RA treatment. We aimed to investigate the effects of etanercept and adalimumab on human Th17-polarized cells and the possible intracellular regulators of these effects, including the Th17-specific transcription factors signal transducer, activator of transcription 3 (STAT3), retinoid-related orphan receptor Y-T (RORYt) and epigenetic modification. Human CD4 ${ }^{+} \mathrm{T}$ cells from healthy subjects and patients with RA were pretreated with TNF-a inhibitors and then being polarized into IL-17-producing cells. The Th17-related cytokine levels in the culture supernatants were determined with an enzyme-linked immunosorbent assay. Intracellular signalling was investigated by western blot, real-time RT-PCR, and chromatin immunoprecipitation. Th17-polarized cells from patients with RA produced more IL-17A, IL-17F and IL-22 than those from healthy subjects. Etanercept and adalimumab suppressed IL-17A, IL-17F and IL-22 levels in Th17-polarized cells from healthy subjects and patients with RA. Western blot analysis revealed that etanercept and adalimumab decreased mitogenactivated protein kinase-phospho-p38, nuclear factor-kB-phospho-p65, phosphoSTAT3 and RORyt levels. Etanercept and adalimumab decreased histone (H)3 and H4 acetylation in the RORyt gene promotor region by decreasing the recruitment of the acetyltransferases p300, CBP and PCAF. The present study broadens our knowledge of the mechanisms underlying the immunomodulatory effects of TNF-a inhibitors in rheumatoid arthritis treatment. 


\section{INTRODUCTION}

Rheumatoid arthritis (RA), characterized by joint inflammation, synovial hyperplasia and excessive bone resorption, is mediated by many immune cells and inflammatory cytokines. T helper (Th) 17 cells, a distinct lineage of Th cells, produce interleukin (IL)-17 and play an important role in RA [1]. The frequency of Th17 cells is reportedly higher in peripheral blood mononuclear cells from patients with RA than healthy subjects [2]. Higher IL-17 levels were found to be produced by RA synovium but not osteoarthritis, and these high IL-17 levels were positively correlated with the severity of the disease $[3,4]$.

TNF- $\alpha$ inhibitors, which are biologic agents blocking TNF- $\alpha$, represent a breakthrough in the treatment of RA [5]. Etanercept (Enbrel ${ }^{\mathrm{TM}}$ ) is a recombinant protein consisting of the human TNF receptor coupled with the Fc portion of human IgG. Adalimumab (Humira ${ }^{\mathrm{TM}}$ ) is a human anti-human TNF- $\alpha$ antibody. Both etanercept and adalimumab have been approved by the U.S. Food and Drug Administration (FDA) for human use to prevent inflammatory processes in RA. In RA patients treated with TNF- $\alpha$ inhibitors, serum Th17-related cytokines decreased significantly in parallel with clinical remission in the responders, whereas increased percentage of Th17 cell and elevating related cytokine levels were found in non-responders $[6,7]$. However, mechanisms of how these TNF- $\alpha$ inhibitors suppress cytokine production, especially the immunomodulatory effects on Th17 cells, are yet to be elucidated.

The mitogen-activated protein kinase (MAPK) and nuclear factor- $\mathrm{\kappa B}(\mathrm{NF} \kappa \mathrm{B})$ pathways, which could be activated by TNF receptor, have been found to affect cytokine gene expression that are associated with the pathogenesis of RA $[8,9]$. MAPKs, including ERK, p38 and JNK, are considered the possible therapeutic targets for RA because they regulate proinflammatory cytokine production and play important roles in the signalling cascades $[10,11]$. NFKB is central to the production of proinflammatory mediators in the inflamed synovium of RA. Once activated, the ability of NFKB to induce transcription can further be enhanced by post-translational phosphorylation and acetylation [12, 13]. Signal transducer and activator of transcription 3 (STAT3) and retinoic acidrelated orphan receptor gamma $\mathrm{t}(\mathrm{ROR} \gamma \mathrm{t})$ are linagespecific transcription factors that function in Th17 differentiation $[14,15]$. In rheumatoid synovial T cells, modulation of STAT3 suppresses Th17 differentiation and increases the proportion of regulatory $\mathrm{T}$ cells [16]. It has been reported that ROR $\gamma$ t-specific transcriptional inhibition suppresses autoimmunity associated with Th17 cells [17]. Because MAPKs, NFkB, STAT3 and ROR $\gamma t$ are key regulators in RA pathogenesis and Th17 differentiation, we investigated whether etanercept and adalimumab would exert immunomodulatory effects on Th17-polarized cells by regulating these mediators.

Epigenetics refers to heritable changes in gene function that do not involve changes in nucleotide sequence [18]. Epigenetic changes can result in gene dysregulation, causing various pathological conditions, including autoimmune diseases. Recently, efforts to understand the non-genetic contributions to RA susceptibility have focused on investigating epigenetic mechanisms $[19,20]$. There are increasing studies about the role of epigenetics in DNA methylation in RA synovial fibroblasts or peripheral blood mononuclear cells (PBMCs) but less about histone modifications [21]. It has been found that the balance between histone acetyltransferase (HAT) and histone deacetylase (HDAC) activity is strongly shifted towards histone acetylation in RA synovial tissue [22, 23]. The roles of TNF- $\alpha$ inhibitors in the epigenetic modifications underlying Th17 differentiation and their functions are still unclear.

In the present study, we examined the effects of etanercept and adalimumab on Th17-related cytokines in Th17-polarized cells from healthy subjects and patients with RA. We further investigated the possible intracellular regulators, including epigenetic modification. Understanding how Th17 cells and their downstream cytokines act at a fundamental level is likely to reveal new strategies for treating RA.

\section{RESULTS}

\section{Induction of IL-17A and IL-17F expression by human $\mathrm{CD4}^{+} \mathrm{T}$ cells in Th17-polarized conditions}

Th17 cells produce specific cytokines, including IL-17A and IL-17F. In the present study, we successfully established Th17-polarized conditions by culturing purified $\mathrm{CD} 4^{+} \mathrm{T}$ cells from human subjects in the presence of rhIL- 2 , rhIL- $1 \beta$, rhIL-23, rhTGF- $\beta$ and rhIL-6 with anti-CD3 antibody, anti-CD28 antibody, anti-hIL-4 antibody and anti-hIFN- $\gamma$ antibody. Compared with conventional $\mathrm{CD} 4^{+} \mathrm{T}$ cells that were co-cultured with anti-CD3 antibody, anti-CD28 antibody and rhIL-2, Th17-polarized cells produced significant amounts of both IL-17A and IL-17F after 5 days of culture, as determined by ELISA analysis (Figures 1A and 1B). 


\section{Etanercept and adalimumab suppress IL-17A and IL-17F expression in human Th17-polarized cells}

Th17-polarized human $\mathrm{CD} 4^{+} \mathrm{T}$ cells were pretreated with etanercept at 1 and $0.1 \mu \mathrm{g} / \mathrm{mL}$ or adalimumab at 1 and $10 \mu \mathrm{g} / \mathrm{mL}$ for $2 \mathrm{~h}$ prior to Th17 polarization. The results revealed that both IL-17A and IL-17F expression in the Th17-polarized cells was significantly suppressed by etanercept $(0.1$ and $1 \mu \mathrm{g} / \mathrm{mL})$ and adalimumab ( 1 and $10 \mu \mathrm{g} / \mathrm{mL}$ ) after 5 days of Th17 polarization (Figure 1C and 1D). Following observation of the suppressive effects of etanercept and adalimumab on IL-17A and IL-17F expression in Th17-polarized cells, we determined the cytotoxic effects of the different concentrations of etanercept and adalimumab using a WST-1 cell viability assay. As illustrated in Figure 1E, neither etanercept $(0.1$ and $1 \mu \mathrm{g} / \mathrm{mL})$ nor adalimumab (1 and $10 \mu \mathrm{g} / \mathrm{mL}$ ) significantly reduced the viability of the Th17-polarized cells compared with vehicle after 5 days of incubation. This result suggested that etanercept and adalimumab exert no cytotoxic effects on Th17-polarized cells.

\section{The effects of etanercept and adalimumab on IL-17A, IL-17F and IL-22 levels in Th17-polarized cells from patients with RA}

We also tested the effects of etanercept and adalimumab on Th17-polarized cells from patients with RA. Supernatants were collected from Th17polarized cells from six patients with RA with or without etanercept $(1 \mu \mathrm{g} / \mathrm{mL})$ or adalimumab (1 and $10 \mu \mathrm{g} / \mathrm{mL})$
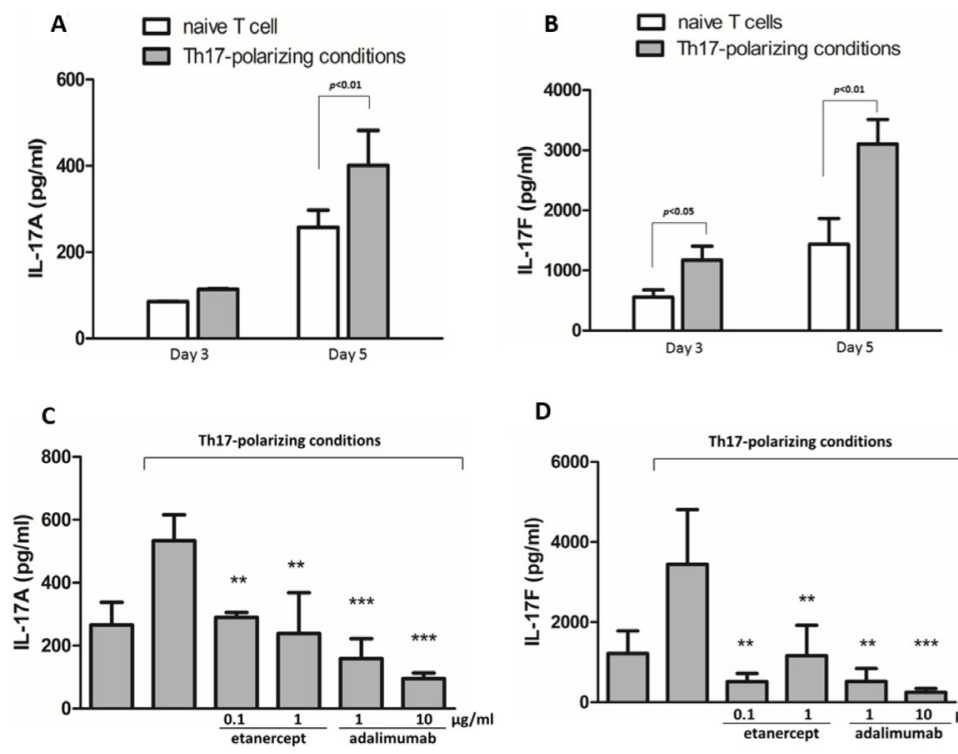

D
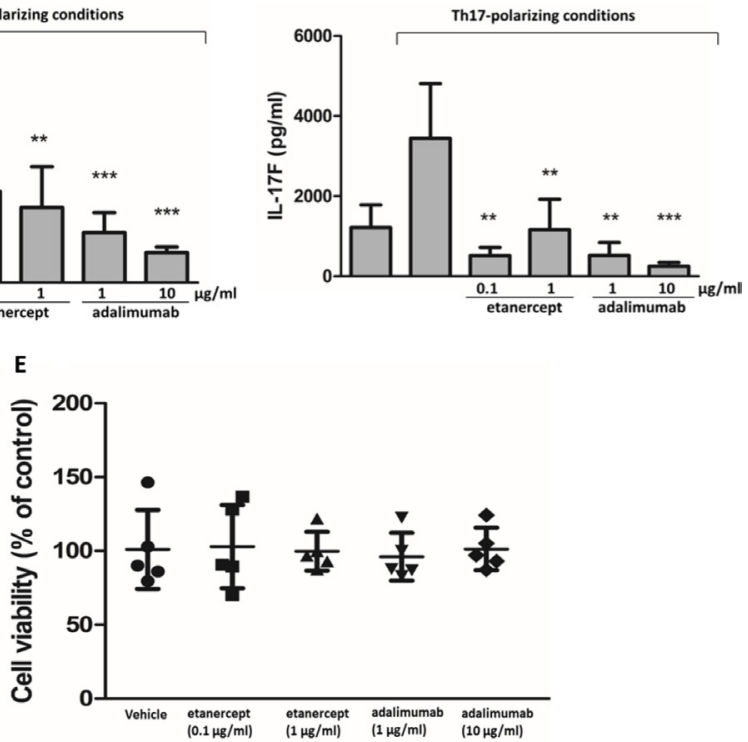

Figure 1: Etanercept and adalimumab suppress IL-17A and IL-17F production in human Th17-polarized T cells. Human naïve $\mathrm{CD} 4{ }^{+}$T cells polarized towards the Th17 phenotype in the presence of rhIL-2, rhIL-1 $\beta$, rhIL-23, rhTGF- $\beta$ and rhIL- 6 with anti-hCD3, anti-hCD28, anti-hIL-4, and anti-hINF- $\gamma$, and then were cultured for 3 days or 5 days. Control naïve T cells were cultured only in the presence of anti-hCD3, antihCD28 and rhIL-2. The supernatants were collected for (A) IL-17A and (B) IL-17F detection by ELISA. The results represent the means \pm standard deviations of three independent experiments. Pretreatment with etanercept $(0.1$ and $1 \mu \mathrm{g} / \mathrm{ml})$ or adalimumab $(1 \mathrm{and} 10 \mu \mathrm{g} / \mathrm{ml}) \operatorname{suppressed}(\mathbf{C}) \mathrm{IL}-17 \mathrm{~A}$ and (D) IL-17F production in human $\mathrm{CD}^{+} \mathrm{T}$ cells from a healthy individual after 5 days of Th17-polarized conditions. The results represent the means \pm standard deviations of three experiments. $* P<0.05$, $* * P<0.01$ and $* * * P<0.001$ between the Th17-polarized conditions with and without TNF- $\alpha$ inhibitor pretreatment. (E) The viability of human $\mathrm{CD}^{+} \mathrm{T}$ cells pretreated with or without etanercept $(0.1 \mathrm{and} 1 \mu \mathrm{g} / \mathrm{ml})$ or adalimumab ( 1 and $10 \mu \mathrm{g} / \mathrm{ml}$ ) was determined after 5 days of Th17 polarization using the WST-1 assay and expressed as a percentage of the control. The results represent the means \pm standard deviations of 5 individual experiments. 
pretreatment in vitro. As illustrated in Figure 2, the supernatants of Th17-polarized cells from patients with RA contained significant amounts of IL-17A, IL-17F and IL-22, and there were statistically significant differences in IL-17F and IL-22 levels compared with cells from healthy subjects. In the RA group, IL-17F expression was significantly suppressed by adalimumab at 1 and $10 \mu \mathrm{g} / \mathrm{mL}$, and IL-22 levels were significantly suppressed by in vitro pretreatment with etanercept at $1 \mu \mathrm{g} / \mathrm{mL}$ or adalimumab at 1 or $10 \mu \mathrm{g} / \mathrm{mL}$ (Figure 2A, 2B and 2C). Th17-polarized cells from patients with RA produced more amount of IL-17A, IL-17F and IL-22 than cells from healthy subjects, and the suppressive effects of TNF- $\alpha$ inhibitors predominantly affected the expression of IL-17F and IL-22.

\section{Etanercept and adalimumab suppress IL-17A, IL-17F and IL-22 production in human Th17- polarized cells through MAPK pathways}

IL-17A expression was suppressed by SB203580 (a p38 inhibitor, $10^{-6}-10^{-5} \mathrm{M}$ ), SP600125 (a Jun NH2terminal kinase (JNK) inhibitor, $10^{-5} \mathrm{M}$ ) and PD98059 (an extracellular signal-related kinase (ERK) inhibitor, $10^{-5} \mathrm{M}$ ) (Figure 3A). IL-17F expression was suppressed by SB203580 $\left(10^{-6} \mathrm{M}\right)$ and SP600125 $\left(10^{-5} \mathrm{M}\right)$ but not PD98059 $\left(10^{-6}-10^{-5} \mathrm{M}\right)$ (Figure 3B). IL-22 expression was suppressed by SB203580 $\left(10^{-5} \mathrm{M}\right), \mathrm{SP} 600125\left(10^{-6}-10^{-5} \mathrm{M}\right)$ and PD98059 $\left(10^{-6}-10^{-5} \mathrm{M}\right)$ (Figure 3C). In western blot analysis, phospho-p38 (p38) expression was significantly suppressed by etanercept at 0.1 and $1 \mu \mathrm{g} / \mathrm{mL}$ and adalimumab at 1 and $10 \mu \mathrm{g} / \mathrm{mL}$ (Figure 3D and 3E), and phospho-ERK (pERK) expression was suppressed by etanercept at 0.1 and $1 \mu \mathrm{g} / \mathrm{mL}$ (Figure $3 \mathrm{~F}$ ) but not by adalimumab (Figure 3G). Western blot analysis indicated that etanercept and adalimumab did not significantly suppress phospho-JNK (pJNK) expression in Th17-polarized cells by (data not shown). These results suggested that the suppression of IL-17A, IL-17F and IL-22 production by etanercept and adalimumab occurs through MAPK pathways in Th17-polarized cells.

\section{Etanercept and adalimumab decrease phosphorylation of NFKB and STAT3 in human Th17-polarized $T$ cells}

The NF $\kappa \mathrm{B}$ pathway plays a key role in regulating the immune response. STAT3 is an important transcription factor in Th17-cell differentiation [24]. As shown in Figure 4, western blot analysis revealed that phospho-p65 (pp65)NFкB levels were significantly suppressed by etanercept at $1 \mu \mathrm{g} / \mathrm{mL}$ (Figure 4A) and adalimumab at 1 and $10 \mu \mathrm{g} / \mathrm{mL}$ (Figure 4B). Phospho-STAT3 (pSTAT3) expression was significantly suppressed by etanercept at 0.1 and $1 \mu \mathrm{g} / \mathrm{mL}$ (Figure 4C) and adalimumab at $10 \mu \mathrm{g} / \mathrm{mL}$ (Figure 4D). These data suggested that etanercept and adalimumab decreased p65-NFkB and STAT3 phosphorylation in Th17-polarized cells.

\section{Histone acetylation is involved in the effects of etanercept and adalimumab on ROR $\gamma \mathrm{t}$ expression in Th17-polarized cells}

Figure 5 shows that etanercept at 0.1 and $1 \mu \mathrm{g} / \mathrm{mL}$ and adalimumab at 1 and $10 \mu \mathrm{g} / \mathrm{mL}$ suppressed ROR $\gamma$ t protein (Figures 5A and 5B) and mRNA (Figure 5C) expression in Th17-polarized cells. Epigenetic modifications are believed to regulate gene expression in RA pathogenesis, so we further examined whether the suppressive effects of etanercept and adalimumab
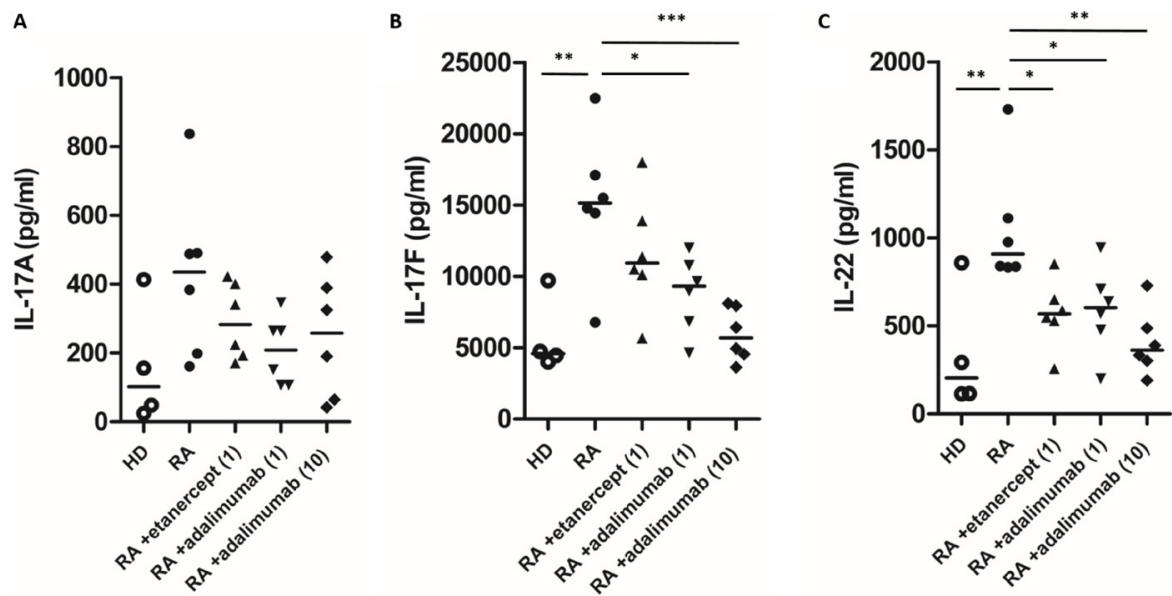

Figure 2: The effects of etanercept and adalimumab on IL-17A, IL-17F and IL-22 production in Th17-polarized cells from patients with RA. The levels of Th17-related cytokines, including (A) IL-17A, (B) IL-17F and (C) IL-22, in the supernatants of Th17-polarized cells from four healthy donors (HD) and six patients with RA that were pretreated in vitro with or without etanercept $(1 \mu \mathrm{g} / \mathrm{ml})$ or adalimumab $(1$ or $10 \mu \mathrm{g} / \mathrm{ml})$ were determined by ELISA. Horizontal bars indicate the median. $* P<0.05, * * P<0.01$ and $* * * P<0.001$. 

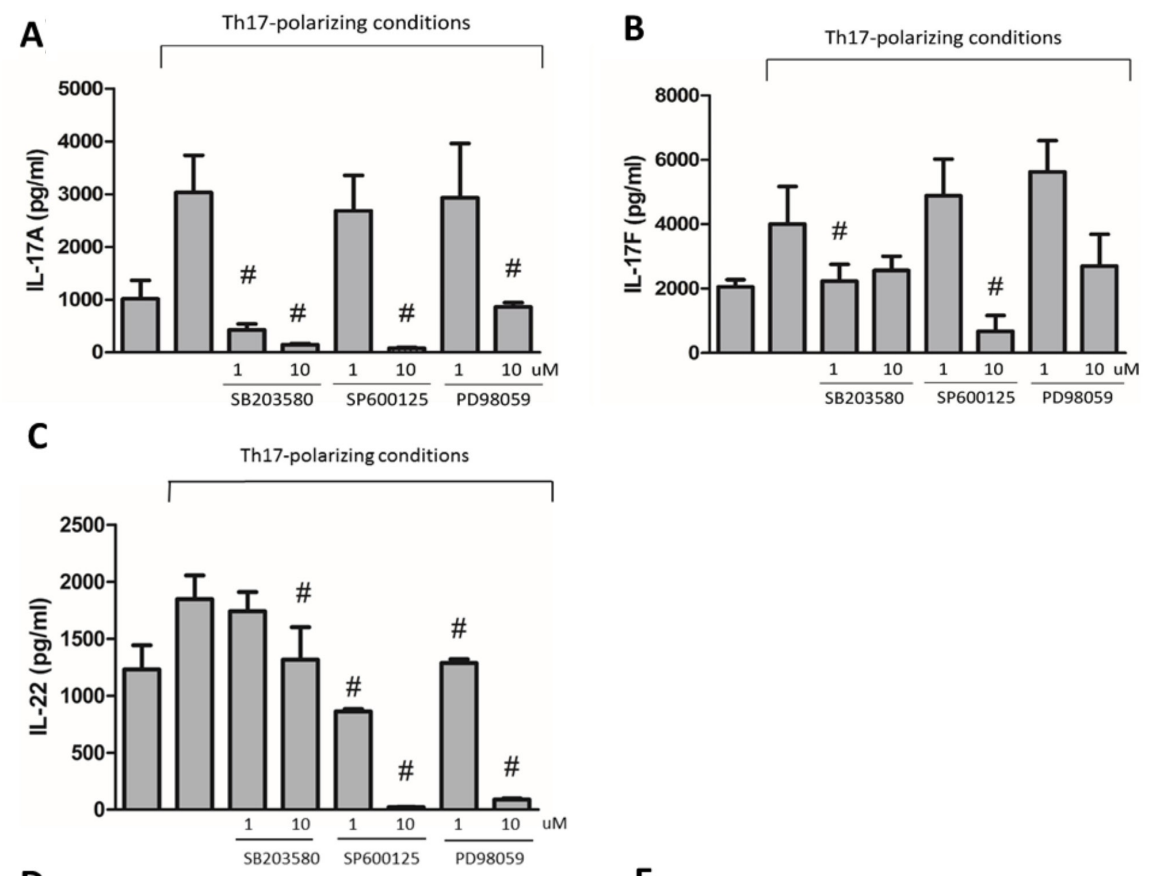

D

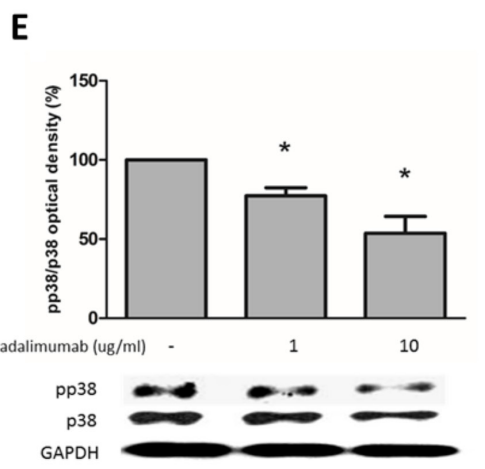

$\mathbf{F}$

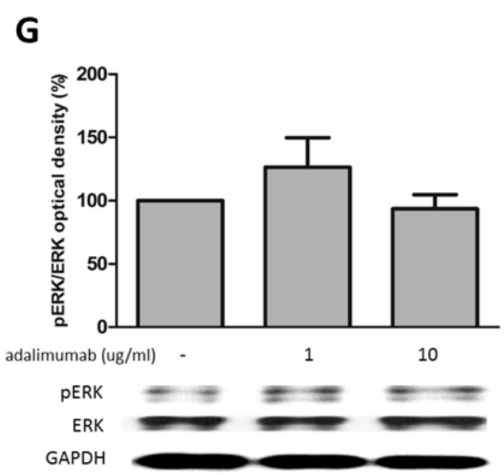

Figure 3: The suppressive effects of etanercept and adalimumab on IL-17A, IL-17F and IL-22 expression in human Th17-polarized cells through MAPK pathways. (A) Human Th17-polarized cells were induced from purified $\mathrm{CD}^{+} \mathrm{T}$ cells from healthy subjects. Pretreatment with SB203580 (a p38 inhibitor, $10^{-6}-10^{-5} \mathrm{M}$ ), SP600125 (a JNK inhibitor, $10^{-5}$ M) or PD98059 (an ERK inhibitor, 10-5 M) significantly suppressed IL-17A expression in Th17-polarized cells. (B) SB203580 $\left(10^{-6} \mathrm{M}\right)$ and SP600125 $\left(10^{-5} \mathrm{M}\right)$ significantly suppressed IL-17F expression in human Th17-polarized cells. (C) Pretreatment with SB203580 $\left(10^{-5} \mathrm{M}\right)$, SP600125 $\left(10^{-6}-10^{-5} \mathrm{M}\right)$ and PD98059 $\left(10^{-6}-10^{-5} \mathrm{M}\right)$ could significantly suppress IL-22 expression in Th17-polarized cells. ${ }^{*} P<0.05$ for the comparison of Th17-polarized conditions with and without MAPK inhibitor pretreatment. (D) Etanercept $(0.1$ and $1 \mu \mathrm{g} / \mathrm{ml})$ and $(\mathbf{E})$ adalimumab (1 and $10 \mu \mathrm{g} / \mathrm{ml})$ decreased pp38 levels in human Th17-polarized cells. (F) Etanercept $(0.1$ and $1 \mu \mathrm{g} / \mathrm{ml})$ but not $(\mathbf{G})$ adalimumab decreased pERK levels in human Th17-polarized cells. For western blot analysis, the standard deviations of the optical density data were calculated for three independent experiments, and one experiment representative of the set of three is shown. ${ }^{*} P<0.05$ for the comparison of Th17-polarized conditions with and without etanercept or adalimumab pretreatment. 
on ROR $\gamma \mathrm{t}$ expression were mediated by epigenetic regulation. As demonstrated in Figure 5D, pretreatment with anacardic acid (a HAT inhibitor) suppressed ROR $\gamma \mathrm{t}$ expression in Th17-polarized cells. This finding suggested that histone acetylation may be involved in ROR $\gamma t$ expression. A chromatin immunoprecipitation (ChIP) assay revealed that etanercept and adalimumab significantly downregulated $\mathrm{H} 3$ and $\mathrm{H} 4$ acetylation in the ROR $\gamma$ t promoter area (Figures $5 \mathrm{E}$ and $5 \mathrm{~F}$ ). These data suggested that TNF- $\alpha$ inhibitors may suppress ROR $\gamma \mathrm{t}$ expression by inhibiting the acetylation of histones $\mathrm{H} 3$ and H4 in Th17-polarized cells. Moreover, because etanercept and adalimumab suppressed NFאB activation, as shown in Figure 4, we used a ChIP assay to verify whether the $\mathrm{NF} \kappa \mathrm{B}$-associated acetyltransferases p300, CBP, and PCAF were involved in histone acetylation. As illustrated in Figure 6, both etanercept and adalimumab significantly decreased the recruitment of p300, CREB-binding protein (CBP) and p300/CBP-associated factor (PCAF) to the ROR $\gamma t$ promoter area. These data suggested that TNF- $\alpha$ inhibitors suppress ROR $\gamma \mathrm{t}$ expression by inhibiting the acetylation of histones $\mathrm{H} 3$ and $\mathrm{H} 4$ by decreasing the recruitment of the histone acetyltransferases p300, CBP and PCAF.

\section{The in vitro effects of etanercept and adalimumab on Th17-related cytokine production in Th17- polarized cells from one RA patient undergoing Enbrel $^{\mathrm{TM}}$ treatment}

Th17-polarized cells from one RA patient treated with weekly subcutaneous injections of $25 \mathrm{mg}$ Enbrel $^{\mathrm{TM}}$ were collected $2 \mathrm{~h}$ before and $48 \mathrm{~h}$ after Enbrel ${ }^{\mathrm{TM}}$ injection. According to the prescribing information [25], the means \pm standard deviations of the half-life and the time to the maximum serum concentration $\left(\mathrm{C}_{\max }\right)$ in patients with RA after subcutaneous injection of $25 \mathrm{mg}$ of Enbrel ${ }^{\mathrm{TM}}$ are $102 \pm 30 \mathrm{~h}$ and $69 \pm 34 \mathrm{~h}$, respectively. Thus, we presumed that the concentration of Enbrel ${ }^{\mathrm{TM}}$ in the patient reached the minimum serum concentration $\left(\mathrm{C}_{\min }\right) 2 \mathrm{~h}$ before subcutaneous injection and reached $\mathrm{C}_{\max } 48 \mathrm{~h}$ after subcutaneous injection.

As illustrated in Figure 7, the supernatants of Th17-polarized cells collected at the EnbrelTM $\mathrm{C}_{\text {min }}$ (shown as "before therapy") contained significant levels of IL-17A, IL-17F and IL-22, and these IL-17F and IL-22 levels were significantly different from the levels in the supernatants collected at the EnbrelTM $\mathrm{C}_{\max }$ (shown as "after therapy"). As shown in Figure 7A, IL-17A expression was not significantly suppressed by in vitro etanercept $(1 \mu \mathrm{g} / \mathrm{mL})$ in Th17-polarized cells collected at either the $\mathrm{C}_{\max }$ or the $\mathrm{C}_{\text {min }}$ of Enbrel ${ }^{\mathrm{TM}}$. Adalimumab at both $1 \mu \mathrm{g} / \mathrm{mL}$ and $10 \mu \mathrm{g} / \mathrm{mL}$ significantly suppressed IL-17A expression in Th17-polarized cells collected at both the $\mathrm{C}_{\max }$ and the $\mathrm{C}_{\text {min }}$ of Enbrel ${ }^{\mathrm{TM}}$. IL-17F and IL-22 levels both were significantly suppressed by in vitro etanercept (1 $\mu \mathrm{g} / \mathrm{mL}$ ) and adalimumab (1 and $10 \mu \mathrm{g} / \mathrm{mL}$ ) in Th17-polarized cells collected at the $\mathrm{C}_{\text {min }}$ of Enbrel ${ }^{\mathrm{TM}}$, but only adalimumab at $10 \mu \mathrm{g} / \mathrm{mL}$ produced significant suppression on these cytokines when cells were collected at the $\mathrm{C}_{\max }$ of Enbrel ${ }^{\mathrm{TM}}$ (Figure 7B and 7C). These results suggest that the ability of Th17-polarized cells to produce cytokines decreased when the patient was treated with higher concentrations of anti-TNF- $\alpha$ therapy. Also, the suppressive effects of a different TNF- $\alpha$ inhibitor on in vitro cytokine production by Th17-polarized cells from the patient treated with anti-TNF- $\alpha$ therapy seemed
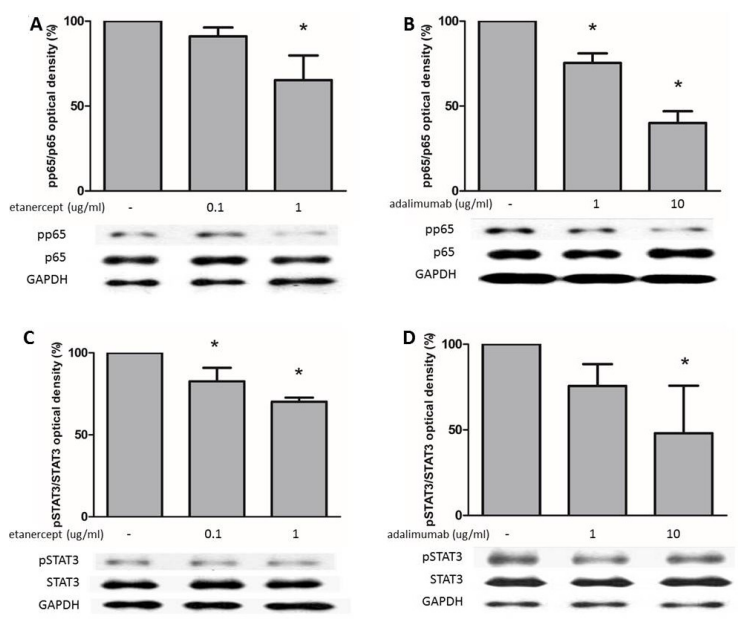

Figure 4: Etanercept and adalimumab downregulate NFאB and STAT3 expression in human Th17-polarized cells. (A) Th17-polarized cells were induced from purified $\mathrm{CD}^{+} \mathrm{T}$ cells from healthy subjects. Etanercept at $1 \mu \mathrm{g} / \mathrm{ml}$ and (B) adalimumab at 1 and $10 \mu \mathrm{g} / \mathrm{ml}$ decreased pp65 levels in human Th17-polarized cells. (C) Etanercept at $0.1 \mathrm{and} 1 \mu \mathrm{g} / \mathrm{ml}$ and (D) adalimumab at $10 \mu \mathrm{g} / \mathrm{ml}$ decreased pSTAT3 levels in human Th17-polarized cells. For western blot analysis, the standard deviations of the optical density data were calculated for three independent experiments, and one experiment representative of the set of three is shown. ${ }^{*} P<0.05$ for the comparison of Th17-polarized conditions with or without etanercept or adalimumab pretreatment. 
to be similar when the inhibitors were used at the same concentration.

\section{DISCUSSION}

The population of Th17 cells is small under physiologic conditions, and factors inducing Th17 cell differentiation in humans are more obscure than those in animal models of arthritis. In the present study, we successfully polarized human $\mathrm{CD}^{+} \mathrm{T}$ cells to produce significant amounts of IL-17A and IL-17F after 5 days of incubation with recombinant TGF- $\beta$, IL-6, IL- $1 \beta$ and IL-23. We demonstrated that IL-17A and IL-17F production by normal Th17-polarized cells were significantly suppressed by both etanercept and adalimumab. The suppressive effects of etanercept and adalimumab were also found in Th17-polarized cells from patients with RA. IL-17A, IL-17F and IL-22 levels were higher in the supernatants of Th17-polarized cells generated from the $\mathrm{CD}^{+} \mathrm{T}$ cells of patients with RA than the cells generated from $\mathrm{CD}^{+} \mathrm{T}$ cells of healthy subjects. This suggests that the $\mathrm{CD} 4^{+} \mathrm{T}$ cells of patients with RA may be more sensitive to Th17 polarization and the associated cytokine production. Moreover, in a patient already receiving regular etanercept treatment, we found that the in vitro suppressive effects of the same concentrations $(1 \mu \mathrm{g} / \mathrm{mL})$ of etanercept and adalimumab were similar, and the suppressive effects of adalimumab on Th17-related cytokine production were significantly greater at a higher therapeutic concentration $(10 \mu \mathrm{g} / \mathrm{mL})$.
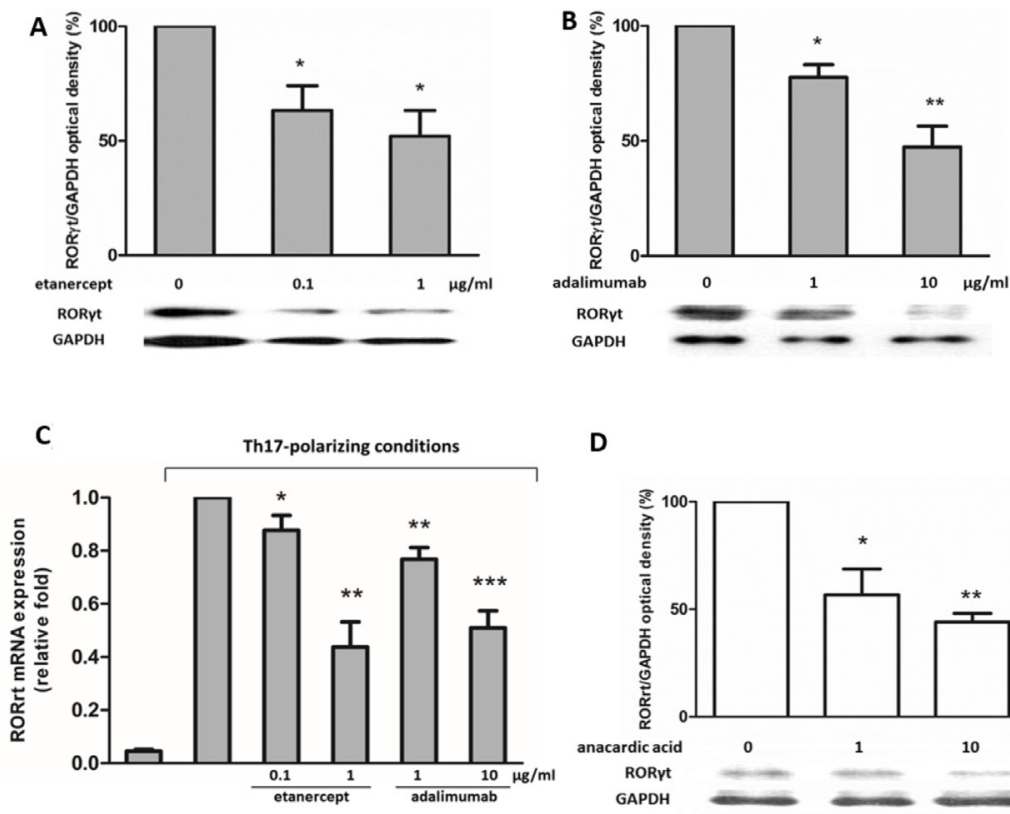

D
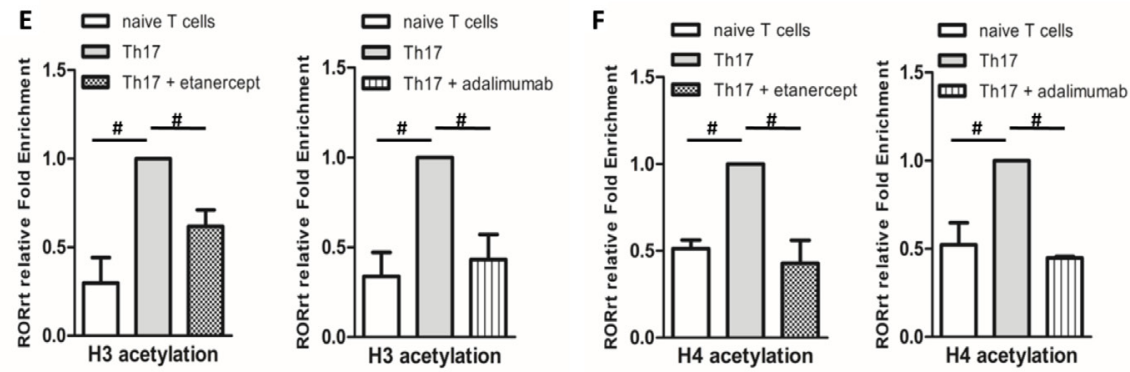

Figure 5: Etanercept and adalimumab downregulate ROR $\gamma \mathrm{t}$ expression in human Th17-polarized T cells via histone acetylation. Western blot analysis revealed that (A) etanercept $(0.1$ and $1 \mu \mathrm{g} / \mathrm{ml})$ and (B) adalimumab $(1$ and $10 \mu \mathrm{g} / \mathrm{ml})$ suppressed ROR $\gamma t$ expression $24 \mathrm{~h}$ after Th17 polarization. (C) Real-time quantitative PCR was used to evaluate ROR $\gamma \mathrm{t}$ mRNA expression in CD4 ${ }^{+}$ $\mathrm{T}$ cells after the cells were cultured under Th17-polarized conditions for $12 \mathrm{~h}$ with or without pretreatment with TNF- $\alpha$ inhibitors for $2 \mathrm{~h}$. The results represent the means \pm standard deviations of three independent experiments. (D) Pretreatment with anacardic acid (an acetyltransferase inhibitor) suppressed ROR $\gamma \mathrm{t}$ expression $24 \mathrm{~h}$ after Th17 polarization. For western blot analysis, the standard deviations of the optical density data were calculated from three independent experiments, and one experiment representative of the set of three is shown. $* P<0.05, * * P<0.01$ and $* * * P<0.001$ between Th17-polarized conditions with and without TNF- $\alpha$ inhibitor pretreatment. ChIP analysis revealed that histone (E) $\mathrm{H} 3$ and (F) H4 acetylation was decreased by etanercept $(1 \mu \mathrm{g} / \mathrm{mL})$ and adalimumab $(10 \mu \mathrm{g} / \mathrm{mL}) 6 \mathrm{~h}$ after Th17polarization. The standard deviations of the ChIP data were calculated from four independent experiments. ${ }^{\sharp} P<0.05$. 
It has been reported that there are associations between adalimumab serum levels and therapeutic response in patients with RA [26]. Baseline adalimumab levels were significantly higher in patients with persistent remission (median $10.5 \mu \mathrm{g} / \mathrm{mL}$ ) than those with disease flare-up (median $0.9 \mu \mathrm{g} / \mathrm{mL}$ ). In our study, the suppressive effects of adalimumab in patients with RA were dose dependent, especially for IL-17F and IL-22 production. These results were in line with clinical observations and might provide further understanding of the therapeutic effects of antiTNF- $\alpha$ therapy.

It has been reported that the TNF receptor facilitates the activation of MAPK kinases (MAPKK) and NFKB (IאB) kinases and subsequently phosphorylates MAPK and $\mathrm{NF} \kappa \mathrm{B}$ [8]. In the present study, TNF- $\alpha$ inhibitors suppressed pp38-MAPK, pERK-MAPK, pp65-NFкB and phospho-STAT3 expression. MAPKs, including p38, ERK and JNK, mediate cytokine production and are part of the signalling cascades downstream of the $\mathrm{T}$ cell receptor (TCR), toll-like receptors (TLRs) and IL-1 and TNF- $\alpha$ receptors [11]. Growth factors, stress stimuli or cytokines can phosphorylate and activate MAPKs, which activate downstream transcription factors such as Elk-1, c-Myc, activator protein 1 (AP-1), activating transcription factor (ATF)-2 and MAPK-activated protein-2 by activating MAPK kinase kinases (MAPKKKs, MEKK) and MAPK kinases (MAPKK, MEK) [27, 28]. Our study found that TNF- $\alpha$ inhibitors suppressed IL-17A, IL-17F and IL-22 production by decreasing p 38 and ERK phosphorylation.
STAT3 and ROR $\gamma \mathrm{t}$ are lineage-specific transcription factors involved in Th17 differentiation. It has been reported that ROR $\gamma \mathrm{t}$ expression alone is insufficient to drive Th17 differentiation, and STAT3 activation augments the expression of ROR $\gamma$ t during Th17 differentiation $[15,29]$. The complete block of TNF $\alpha$-induced STAT3 phosphorylation by p38-MAPK and ERK-MAPK inhibitors suggests a cross talk between the MAPK and STAT3 pathways [30]. In the present study, we found that TNF- $\alpha$ inhibitors suppressed pp38, pERK, and phospho-STAT3 protein expression $1 \mathrm{~h}$ after Th17 polarization, and ROR $\gamma \mathrm{t}$ mRNA expression was suppressed by TNF- $\alpha$ inhibitors $12 \mathrm{~h}$ after Th17 polarization. TNF- $\alpha$ inhibitors decreased IL-17 production through the downregulation of p38-MAPK, ERK-MAPK and STAT3 phosphorylation, which might subsequently suppress ROR $\gamma$ t expression in Th17-polarized cells. These findings suggest a cross talk between the MAPKs and ROR $\gamma \mathrm{t}$ pathways.

An important novel finding in this study is the epigenetic regulation of the ROR $\gamma \mathrm{t}$ gene by TNF- $\alpha$ inhibitors. There is increasing experimental evidence of the pivotal role of epigenetic modifications in RA pathogenesis, but most studies have focused on the regulation of cytokine gene expression [19]. ROR $\gamma t$ has been identified as a Th17-specific transcription factor that induces Th17 differentiation. In the present study, we found that anacardic acid, a nonselective inhibitor of HATs, suppressed ROR $\gamma \mathrm{t}$ expression in Th17-polarized

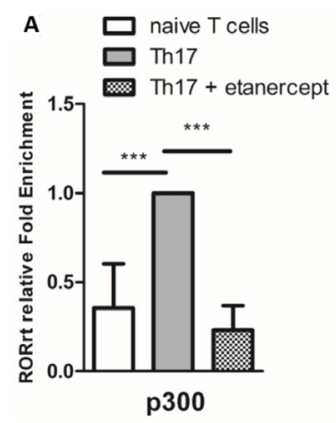

D
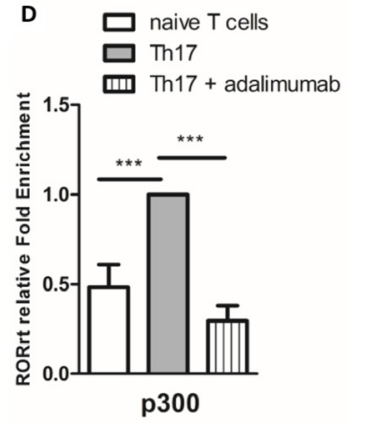

B
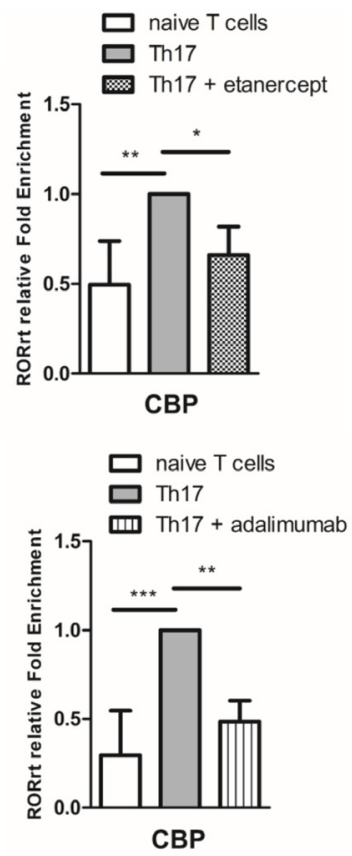

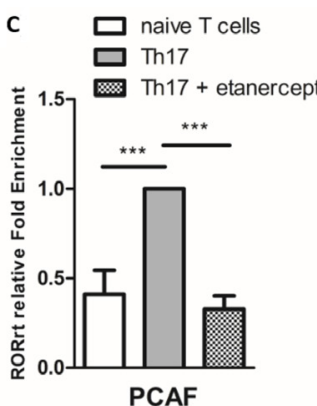

$\mathbf{F}$

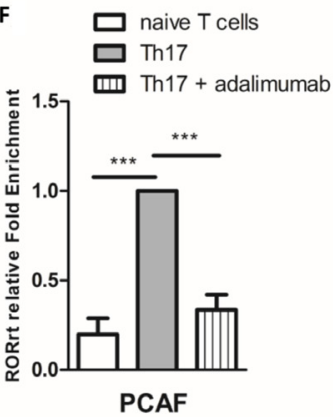

Figure 6: The effects of etanercept and adalimumab on NFkB-associated acetyltransferases in Th17-polarized cells. Etanercept $(1 \mu \mathrm{g} / \mathrm{mL})$ decreased the recruitment of the NFKB-associated acetyltransferases (A) p300, (B) CBP and (C) PCAF in Th17polarized cells induced from purified $\mathrm{CD}^{+} \mathrm{T}$ cells (naïve $\mathrm{T}$ cells). Adalimumab $(10 \mu \mathrm{g} / \mathrm{mL}$ ) decreased the recruitment of the NFkBassociated acetyltransferases (D) p300, (E) CBP and (F) PCAF in Th17-polarized cells. The standard deviations of the ChIP data were calculated from four independent experiments. ${ }^{*} P<0.05,{ }^{*} P<0.01$ and $* * * P<0.001$. 
cells. This finding suggests that histone acetylation is involved in ROR $\gamma$ t expression. $\mathrm{H} 3$ and $\mathrm{H} 4$ acetylation, which commonly referred to as euchromatin modifications, are associated with active transcription [31]; therefore, we examined whether etanercept and adalimumab regulated ROR $y$ t expression through $\mathrm{H} 3$ and $\mathrm{H} 4$ acetylation in this study. To the best of our knowledge, this is the first study to investigate the epigenetic regulation of ROR $\gamma t$ expression in Th17 cells. We found that TNF- $\alpha$ inhibitors could suppress ROR $\gamma$ t protein and mRNA expression in human Th17-polarized cells, and these suppressive effects might be mediated through the downregulation of histone $\mathrm{H} 3$ and $\mathrm{H} 4$ acetylation. It has been reported that $\mathrm{NF} \kappa \mathrm{B}$ induction by $\mathrm{T}$ cell receptor stimulation enhances ROR $\gamma$ t expression by binding to the ROR $\gamma \mathrm{t}$ promotor [32]. NF $\kappa B$ induces transcription after post-translational phosphorylation and acetylation of its subunits and then stimulates histone acetylation with p300, CBP and PCAF, which control gene transcription and have HAT activity [33]. In the present study, etanercept and adalimumab downregulated $\mathrm{NF} \kappa \mathrm{B}$ expression and decreased the recruitment of the acetyltransferases p300, CBP and PCAF to the ROR $\gamma t$ promotor area. These findings suggest that TNF- $\alpha$ inhibitors inhibit the upstream transcription factor $\mathrm{NF} \kappa \mathrm{B}$, which binds to the ROR $\gamma \mathrm{t}$ gene promoter and interacts with the coactivators CBP, p300 and PCAF, influencing the balance of HAT/HDAC activity and histone acetylation in the ROR $\gamma t$ gene.

In addition to the important role of Th17 cells in the development of various autoimmune and inflammatory diseases, Th17 cells also provide host defence against bacterial and fungal infections [34].

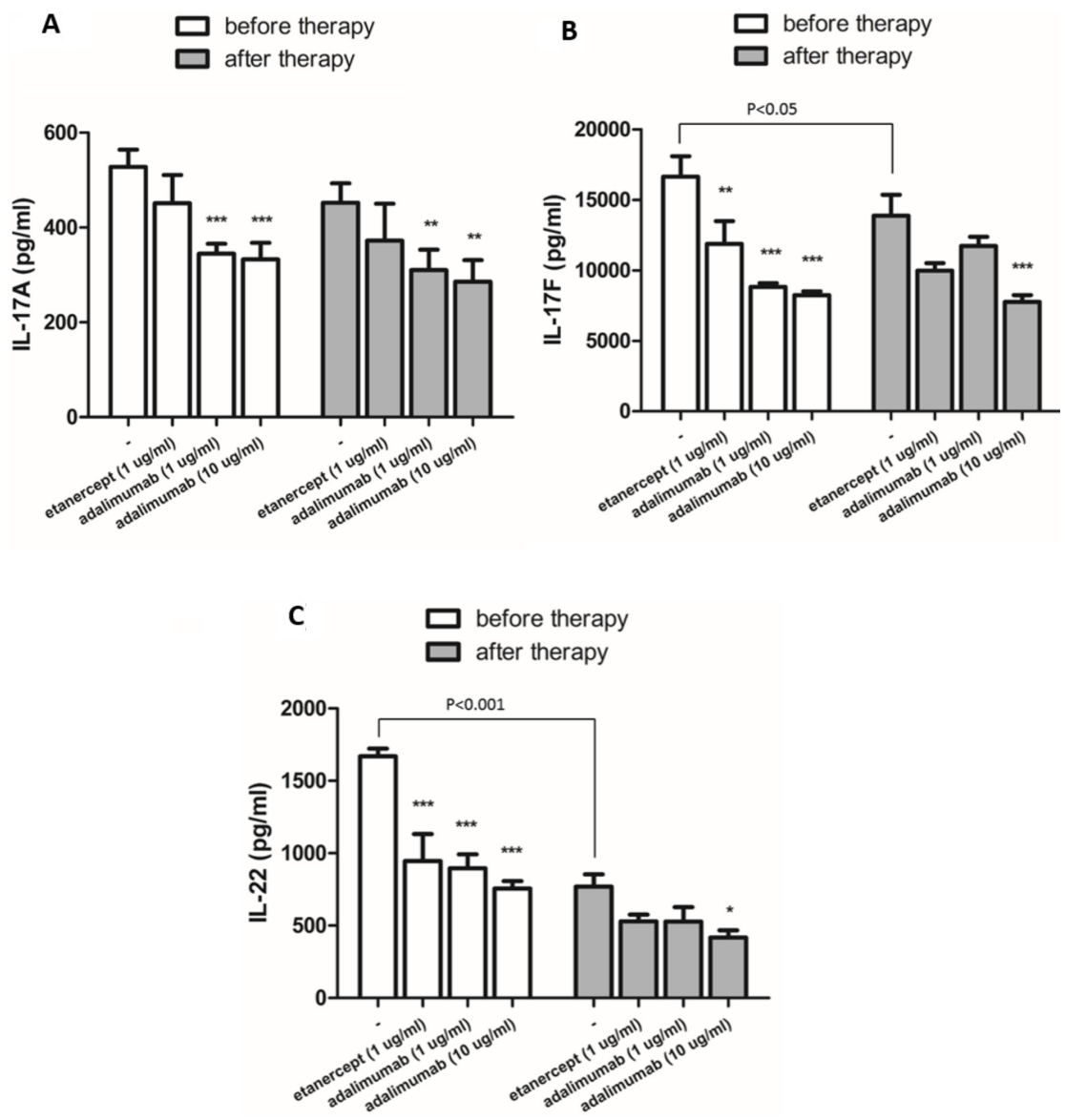

Figure 7: The in vitro effects of etanercept and adalimumab on Th17-related cytokine production by Th17-polarized cells from an RA patient undergoing EnbrelTM treatment. Th17-polarized cells induced from CD4 ${ }^{+} \mathrm{T}$ cells that were collected from an RA patient $2 \mathrm{~h}$ before (at the trough level) and $48 \mathrm{~h}$ after (at the peak level) of Enbrel ${ }^{\mathrm{TM}}$ injection. The in vitro effects of etanercept $(1 \mu \mathrm{g} / \mathrm{mL})$ and adalimumab ( 1 and $10 \mu \mathrm{g} / \mathrm{mL})$ on IL-17A, IL-17F and IL-22 production in Th17-polarized cells were determined by ELISA. $P$-values indicate comparison of the cytokine levels before and after EnbrelTM injection. (A) IL-17A production by Th17-polarized cells isolated from the RA patient $2 \mathrm{~h}$ before and $48 \mathrm{~h}$ after Enbrel ${ }^{\mathrm{TM}}$ injection was significantly suppressed by in vitro treatment with adalimumab (1 and $10 \mu \mathrm{g} / \mathrm{mL}$ ) but not etanercept $(1 \mu \mathrm{g} / \mathrm{mL}$ ). (B) IL-17F and (C) IL-22 production was significantly suppressed by in vitro treatment with etanercept $(1 \mu \mathrm{g} / \mathrm{mL})$ and adalimumab $(1 \mu \mathrm{g} / \mathrm{mL})$ when cells were isolated from the RA patient $2 \mathrm{~h}$ before but not $48 \mathrm{~h}$ after Enbrel ${ }^{\mathrm{TM}}$ injection. In vitro pretreatment with adalimumab $(10 \mu \mathrm{g} / \mathrm{mL})$ significantly suppressed IL-17F and IL-22 production both before and after Enbrel $^{\mathrm{TM}}$ injection. The bars represent the means \pm standard deviations from three independent experiments. $* P<0.05, * * P<0.01$ and $* * * P<0.001$ between the Th17-polarized cells with and without in vitro etanercept or adalimumab pretreatment. 
Although TNF- $\alpha$ inhibitors exhibit significant clinical efficacy, they have many potential adverse effects, including reactivation of mycobacterial and fungal infection [35]. Previous studies have demonstrated that $\mathrm{ROR} \gamma \mathrm{t}$ is required in mucocutaneous immunity to Candida and systemic immunity to Mycobacterium, and decreased pSTAT3 expression reduced IL-17 production in $\mathrm{CD}^{+} \mathrm{T}$ cells from tuberculosis patients [36, 37]. It has also been reported that p38-MAPK, NFкB and STAT3 play key roles in tissue destruction in patients with tuberculosis [38]. Our results on the suppression mechanisms of etanercept and adalimumab in Th17 polarization and cytokine production also provide additional understanding of the adverse effects of TNF- $\alpha$ inhibitors in reactivation of infection.

In conclusion, the present study provides further understanding of the TNF- $\alpha$ inhibitor-mediated suppression of the intracellular signalling pathways underlying Th17 differentiation and related cytokine production (Figure 8). Two common TNF- $\alpha$ inhibitors, etanercept and adalimumab, suppressed IL-17-related cytokine production through the p38-MAPK, ERK-MAPK and p65-NFкB pathways in Th17-polarized cells and downregulated phosphorylation of the linage-specific transcription factor STAT3 and histone acetylation at the ROR $\gamma \mathrm{t}$ gene. Some of the therapeutic efficacy of TNF- $\alpha$ inhibitors might result from the downregulation of these key transcription factors in Th17 cells. The present study established an experimental model of IL-17-producing cells polarized from human $\mathrm{CD}^{+}$cells and broadened our knowledge of the mechanism of TNF- $\alpha$ inhibitors in rheumatoid arthritis treatment.

\section{MATERIALS AND METHODS}

\section{Purification and culture of $\mathrm{CD}^{+} \mathrm{T}$ cells}

The study protocol was approved by the Institutional Review Board of Kaohsiung Medical University Hospital in Kaohsiung, Taiwan. Informed consent was obtained according to the Declaration of Helsinki. Four healthy subjects and six patients with RA were enrolled. Among these patients with RA, two were being treated with etanercept, three were being treated with adalimumab and one was being treated with metronidazole without any TNF- $\alpha$ inhibitors. PBMCs were isolated by densitygradient centrifugation (Lymphoprep ${ }^{\mathrm{TM}}$, Axis-Shield PoC AS, Oslo, Norway). Human $\mathrm{CD}^{+} \mathrm{T}$ cells were isolated from PBMCs by using microbeads (negative selection) according to the manufacturer's protocol (MACS, Miltenyi Biotec, Bergisch Gladbach, Germany). The purity of the $\mathrm{CD}^{+} \mathrm{T}$ cell population, which was analysed by flow cytometry, was more than $95 \%$. Human $\mathrm{CD}^{+} \mathrm{T}$ cells were cultured in 24-well flat-bottomed plates at a density of $5 \times 10^{5}$ cells $/ \mathrm{mL}$ with anti-human CD3 mAb $(1 \mu \mathrm{g} / \mathrm{mL})$, anti-human CD28 mAb $(1 \mu \mathrm{g} / \mathrm{mL})$, and recombinant human (rh) IL-2 (5 ng/mL) in RPMI 1640 culture medium (Sigma Chemical Co., Saint Louis, Missouri, USA) supplemented with $10 \%$ foetal bovine serum, $100 \mathrm{U} / \mathrm{mL}$ penicillin, and $100 \mu \mathrm{g} / \mathrm{mL}$ streptomycin at $37^{\circ} \mathrm{C}$ with $5 \% \mathrm{CO}_{2}$.

\section{Generation of Th17-polarized conditions from human $\mathrm{CD4}^{+} \mathrm{T}$ cells}

Th17-polarized conditions were generated by culturing human $\mathrm{CD}^{+} \mathrm{T}$ cells $\left(5 \times 10^{5} / \mathrm{mL}\right)$ with rhIL-2

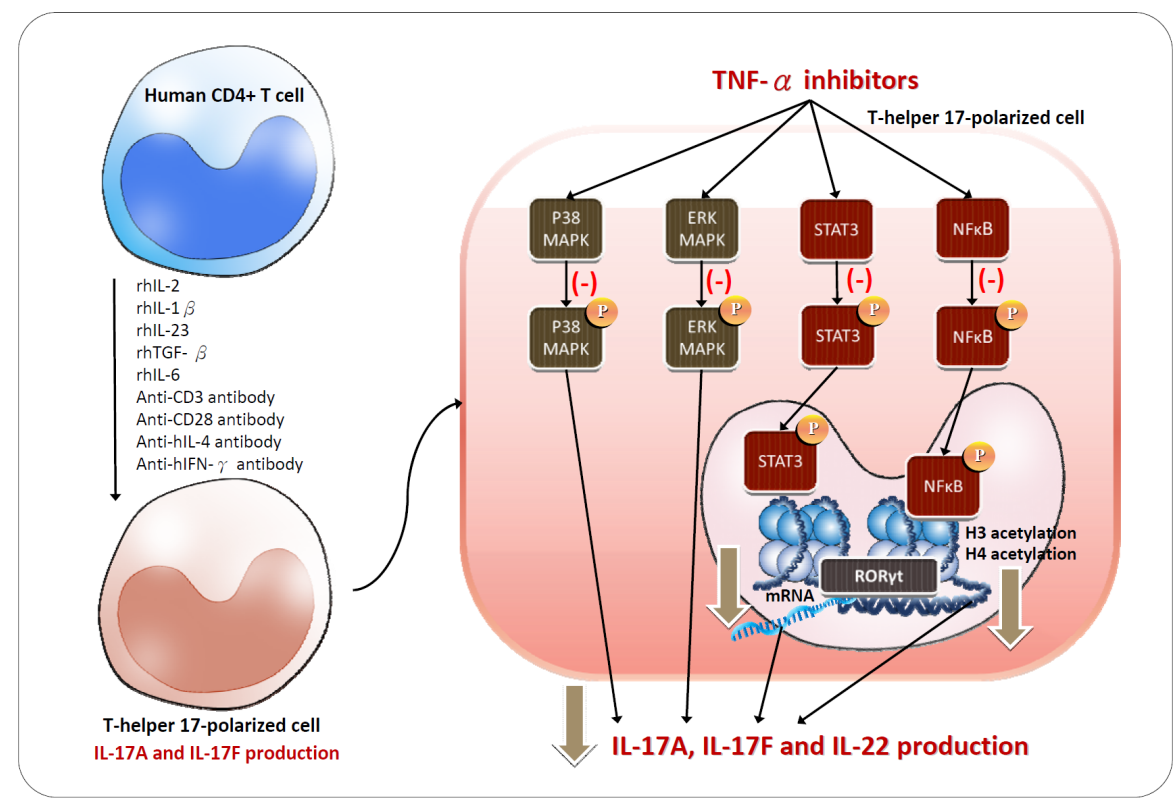

Figure 8: Schematic of the proposed intracellular mechanisms underlying TNF- $\alpha$ inhibitor regulation in Th17 cells polarized from $\mathrm{CD4}^{+} \mathrm{T}$ cells. 
(5 ng/mL), rhTGF- $\beta(0.05 \mathrm{ng} / \mathrm{mL})$, rhIL-6 $(20 \mathrm{ng} / \mathrm{mL})$, rhIL-1 $\beta$ (10 ng/mL), rhIL-23 (10 ng/mL), anti-hIL-4 mAb $(1 \mathrm{mg} / \mathrm{mL})$, anti-hIFN- $\gamma \mathrm{mAb}(1 \mathrm{mg} / \mathrm{mL})$, anti-hCD3 $\mathrm{mAb}(1 \mathrm{mg} / \mathrm{mL})$, and anti-hCD28 $\mathrm{mAb}(1 \mathrm{mg} / \mathrm{mL})$ in a 24-well flat-bottomed plate in complete RPMI 1640 culture medium at $37^{\circ} \mathrm{C}$ with $5 \% \mathrm{CO}_{2}$. Cells were pretreated with etanercept $\left(\right.$ Enbrel $^{\circledR}$; Immunex Corporation, Thousand Oaks, California, USA) or adalimumab (Humira ${ }^{\circledR}$; AbbVie Incorporated, North Chicago, Illinois, USA) for $2 \mathrm{~h}$ and then stimulated with the Th17-polarized panel. To reduce pharmacokinetic variability between etanercept and adalimumab, the concentrations of these two TNF- $\alpha$ inhibitors were selected based on the therapeutic concentrations in the U.S. FDA-approved package inserts and clinical reports. $\mathrm{A} \mathrm{C}_{\max }$ of $1.1 \pm 0.6 \mathrm{mcg} / \mathrm{mL}$ was observed in patients with RA following a single $25 \mathrm{mg}$ dose [25]. In patients with RA receiving $40 \mathrm{mg}$ of Humira ${ }^{\circledR}$ every other week, adalimumab mean steadystate trough concentrations range from approximately 5 to $9 \mu \mathrm{g} / \mathrm{mL}$ [39]. Previous studies have reported that the cut-off trough levels of etanercept and adalimumab for a good therapeutic response in patients with RA are 1.046 to $1.56 \mu \mathrm{g} / \mathrm{mL}$ and 1.274 to $1.336 \mu \mathrm{g} / \mathrm{mL}$, respectively $[40,41]$. Therefore, etanercept was used at sub-therapeutic and therapeutic concentrations $(0.1$ and $1 \mu \mathrm{g} / \mathrm{mL})$, and adalimumab was used at therapeutic and higher concentrations ( 1 and $10 \mu \mathrm{g} / \mathrm{mL}$ ) in our study. The cell supernatants were collected after 5 days of Th17-polarized conditions.

To investigate cell signalling, the cells were pretreated with a p38-MAPK inhibitor (SB203580), JNK-MAPK inhibitor (SP600125) or ERK-MAPK inhibitor (PD98059) for $1 \mathrm{~h}$ before Th17 polarization. The concentration used in the experiments was based on the half-maximal inhibitory concentration (IC50) of each MAPK inhibitor and previous studies [42]. All the MAPK inhibitors were purchased from Cayman Chemical Company. Supernatants were collected for cytokine measurement.

\section{Enzyme-linked immunosorbent assay (ELISA)}

Supernatant concentrations of IL-17A, IL-17F and IL-22 were measured with ELISA kits according to the manufacturer's protocol (R\&D Systems Inc., Minneapolis, Minnesota, USA). The samples were measured with a Dynatech MRX plate reader at 450 and $540 \mathrm{~nm}$ using Revelation Software (Dynatech Laboratories Ltd., Virginia, USA).

\section{Cell viability}

Th17-polarized cells were incubated with or without etanercept or adalimumab at various concentrations for $2 \mathrm{~h}$ prior to Th17 polarization. Cell viability after the 5-day Th17 polarization was examined using the CytoScan
WST-1 Cell Proliferation Assay (G-Biosciences, Maryland Heights, MO, USA) according to the instructions of the manufacturer. The cell viabilities of each group were expressed as percentages of the control value.

\section{Western blotting}

After treatment for $2 \mathrm{~h}$ with or without etanercept $(0.1$ and $1 \mu \mathrm{g} / \mathrm{mL})$ or adalimumab (1 and $10 \mu \mathrm{g} / \mathrm{mL})$, cells were stimulated with the Th17-polarized panel and subsequently lysed with an equal volume of ice-cold lysis buffer $(150 \mu \mathrm{l}) 1 \mathrm{~h}$ later for MAPKs, p65-NFkB and STAT3 signalling and $24 \mathrm{~h}$ later for ROR $\gamma \mathrm{t}$ signalling. After centrifugation at $13,000 \times \mathrm{g}$ for $15 \mathrm{~min}$, cell lysates were analysed by western blot with anti-MAPK (p38 and ERK), anti-phospho-MAPK (pp38 and pERK), anti-p65, anti-phospho-p65, anti-STAT3, anti-phospho-STAT3, and anti-ROR $\gamma$ t antibodies (Santa Cruz Biotechnology, Santa Cruz, California, USA). The immunoreactive bands were visualized using a horseradish peroxidase-conjugated secondary antibody and an enhanced chemiluminescence system (Amersham Pharmacia Biotech, Sunnyvale, California, USA).

\section{RNA extraction and real-time RT-PCR}

Isolated human $\mathrm{CD}^{+} \mathrm{T}$ cells pretreated with etanercept $(0.1$ or $1 \mu \mathrm{g} / \mathrm{mL})$ or adalimumab (1 or $10 \mu \mathrm{g} / \mathrm{mL}$ ) for $2 \mathrm{~h}$ and were stimulated to become Th17polarizing cells as described above. Total RNA was extracted from cells $12 \mathrm{~h}$ after Th17 polarization. RNA from each sample was reverse transcribed to first-strand cDNA using a SuperScript ${ }^{\mathrm{TM}}$ First-Strand Synthesis System with an RT-PCR kit (Invitrogen, Carlsbad, California, USA). Measurements were made with an ABI PRISM 9700 HT sequence detection system (Applied Biosystems, Foster City, California, USA) using a TaqMan probe/primer combination for ROR $\gamma \mathrm{t}$ and glyceraldehyde 3-phosphate dehydrogenase (GAPDH) from the same cDNA samples. TaqMan PCR was performed using AmpliTaq Gold polymerase and Universal Master Mix (Applied Biosystems, Foster City, California, USA). Threshold cycle numbers were transformed using the comparative threshold cycle and relative value methods according to the manufacturer's recommendation and were expressed relative to GAPDH.

\section{Chromatin immunoprecipitation (ChIP) assay}

ChIP was performed as described previously [42] with minor modifications. Antibodies against acetylated $\mathrm{H} 3$ and $\mathrm{H} 4$ as markers of gene activation [31] and antibodies against p300, CBP, and PCAF as NFкB-associated acetyltransferases were used [33]. Antibodies for the ChIP assay were purchased from Upstate Biotechnology Company. The primers 
were designed as previously described to analyse the promoter regions in the ROR $\gamma \mathrm{t}$ gene (forward: 5'-AGGCTGCACCACACTGG-3', position: -599; reverse: 5'-TTCTACTCCTCCTACCCCCG-3', position: -429) [43].

\section{Statistical analysis}

Differences between the control and experimental groups were analysed using the Mann-Whitney $U$ test. Differences in the intensities of the PCR-amplified products in the ChIP assay and the densitometry results in the western blot experiments between the control and experimental groups were analysed with Wilcoxon's signed-rank test. $P$-values less than 0.05 were considered significant.

\section{ACKNOWLEDGMENTS AND FUNDING}

This study was supported by grants from the Ministry of Science and Technology (MOST 104-2320-B-037-014-MY3; MOST 104-2314-B-037070-MY3; MOST 103-2314-B-037-013), the Research Center for Environmental Medicine, Kaohsiung Medical University (KMU-TP104A06), the Kaohsiung Medical University Hospital Research Foundation (KMUH1022T04 and KMUH104-4M58), and the Kaohsiung Municipal Hsiao-Kang Hospital Research Foundation (KMHKH-103-013 and KMUHKH-104-003).

\section{CONFLICTS OF INTEREST}

None.

\section{REFERENCES}

1. Azizi G, Jadidi-Niaragh F, Mirshafiey A. Th17 Cells in Immunopathogenesis and treatment of rheumatoid arthritis. Int J Rheum Dis. 2013; 16:243-253.

2. Shen H, Goodall JC, Hill Gaston JS. Frequency and phenotype of peripheral blood Th17 cells in ankylosing spondylitis and rheumatoid arthritis. Arthritis Rheum. 2009; 60:1647-1656.

3. Chabaud M, Durand JM, Buchs N, Fossiez F, Page G, Frappart L, Miossec P. Human interleukin-17: A T cell-derived proinflammatory cytokine produced by the rheumatoid synovium. Arthritis Rheum. 1999; 42:963-970.

4. Metawi SA, Abbas D, Kamal MM, Ibrahim MK. Serum and synovial fluid levels of interleukin-17 in correlation with disease activity in patients with RA. Clin Rheumatol. 2011; 30:1201-1207.

5. Hyrich KL, Watson KD, Silman AJ, Symmons DP. Predictors of response to anti-TNF-alpha therapy among patients with rheumatoid arthritis: results from the British Society for Rheumatology Biologics Register. Rheumatology (Oxford). 2006; 45:1558-1565.
6. Chen DY, Chen YM, Chen HH, Hsieh CW, Lin CC, Lan JL. Increasing levels of circulating Th17 cells and interleukin-17 in rheumatoid arthritis patients with an inadequate response to anti-TNF-alpha therapy. Arthritis Res Ther. 2011; 13:R126.

7. Zivojinovic SM, Pejnovic NN, Sefik-Bukilica MN, Kovacevic LV, Soldatovic, II, Damjanov NS. Tumor necrosis factor blockade differentially affects innate inflammatory and Th17 cytokines in rheumatoid arthritis. J Rheumatol. 2012; 39:18-21.

8. Karin M, Gallagher E. TNFR signaling: ubiquitinconjugated TRAFfic signals control stop-and-go for MAPK signaling complexes. Immunol Rev. 2009; 228:225-240.

9. Simmonds RE, Foxwell BM. Signalling, inflammation and arthritis: NF-kappaB and its relevance to arthritis and inflammation. Rheumatology (Oxford). 2008; 47:584-590.

10. Mavers M, Ruderman EM, Perlman H. Intracellular signal pathways: potential for therapies. Curr Rheumatol Rep. 2009; 11:378-385.

11. Paunovic V, Harnett MM. Mitogen-activated protein kinases as therapeutic targets for rheumatoid arthritis. Drugs. 2013; 73:101-115.

12. Chen LF, Greene WC. Shaping the nuclear action of NF-kappaB. Nat Rev Mol Cell Biol. 2004; 5:392-401.

13. Doyle SL, O'Neill LA. Toll-like receptors: from the discovery of NFkappaB to new insights into transcriptional regulations in innate immunity. Biochem Pharmacol. 2006; 72:1102-1113.

14. Yang XO, Panopoulos AD, Nurieva R, Chang SH, Wang D, Watowich SS, Dong C. STAT3 regulates cytokine-mediated generation of inflammatory helper T cells. J Biol Chem. 2007; 282:9358-9363.

15. Ivanov, II, McKenzie BS, Zhou L, Tadokoro CE, Lepelley A, Lafaille JJ, Cua DJ, Littman DR. The orphan nuclear receptor RORgammat directs the differentiation program of proinflammatory IL-17+ T helper cells. Cell. 2006; 126:1121-1133.

16. Ju JH, Heo YJ, Cho ML, Jhun JY, Park JS, Lee SY, Oh HJ, Moon SJ, Kwok SK, Park KS, Park SH, Kim HY. Modulation of STAT-3 in rheumatoid synovial $\mathrm{T}$ cells suppresses Th17 differentiation and increases the proportion of Treg cells. Arthritis Rheum. 2012; 64:3543-3552.

17. Park TY, Park SD, Cho JY, Moon JS, Kim NY, Park K, Seong RH, Lee SW, Morio T, Bothwell AL, Lee SK. RORgammat-specific transcriptional interactomic inhibition suppresses autoimmunity associated with TH17 cells. Proc Natl Acad Sci USA. 2014; 111:18673-18678.

18. Bernstein BE, Meissner A, Lander ES. The mammalian epigenome. Cell. 2007; 128:669-681.

19. Picascia A, Grimaldi V, Pignalosa O, De Pascale MR, Schiano C, Napoli C. Epigenetic control of autoimmune diseases: from bench to bedside. Clin Immunol. 2015; $157: 1-15$. 
20. Klein K, Gay S. Epigenetics in rheumatoid arthritis. Curr Opin Rheumatol. 2015; 27:76-82.

21. Viatte S, Plant D, Raychaudhuri S. Genetics and epigenetics of rheumatoid arthritis. Nat Rev Rheumatol. 2013; 9:141-153.

22. Huber LC, Brock M, Hemmatazad H, Giger OT, Moritz F, Trenkmann M, Distler JH, Gay RE, Kolling C, Moch H, Michel BA, Gay S, Distler O, et al. Histone deacetylase/ acetylase activity in total synovial tissue derived from rheumatoid arthritis and osteoarthritis patients. Arthritis Rheum. 2007; 56:1087-1093.

23. Kawabata T, Nishida K, Takasugi K, Ogawa H, Sada K, Kadota Y, Inagaki J, Hirohata S, Ninomiya Y, Makino H. Increased activity and expression of histone deacetylase 1 in relation to tumor necrosis factor-alpha in synovial tissue of rheumatoid arthritis. Arthritis Res Ther. 2010; 12:R133.

24. Dong C. TH17 cells in development: an updated view of their molecular identity and genetic programming. Nat Rev Immunol. 2008; 8:337-348.

25. Thousand Oaks C. USA: Amgen Inc. and Wyeth Pharmaceuticals; 2009. Enbrel ${ }^{\circledR}$ (etanercept) for subcutaneous injection [prescribing information].

26. Chen DY, Chen YM, Hsieh TY, Hung WT, Hsieh CW, Chen HH, Tang KT, Lan JL. Drug trough levels predict therapeutic responses to dose reduction of adalimumab for rheumatoid arthritis patients during 24 weeks of follow-up. Rheumatology (Oxford). 2016; 55:143-148.

27. Pearson G, Robinson F, Beers Gibson T, Xu BE, Karandikar M, Berman K, Cobb MH. Mitogen-activated protein (MAP) kinase pathways: regulation and physiological functions. Endocr Rev. 2001; 22:153-183.

28. Turjanski AG, Vaque JP, Gutkind JS. MAP kinases and the control of nuclear events. Oncogene. 2007; 26:3240-3253.

29. Mathur AN, Chang HC, Zisoulis DG, Stritesky GL, Yu Q, O'Malley JT, Kapur R, Levy DE, Kansas GS, Kaplan MH. Stat3 and Stat4 direct development of IL-17-secreting Th cells. J Immunol. 2007; 178:4901-4907.

30. Andres RM, Hald A, Johansen C, Kragballe K, Iversen L. Studies of Jak/STAT3 expression and signalling in psoriasis identifies STAT3-Ser727 phosphorylation as a modulator of transcriptional activity. Exp Dermatol. 2013; 22:323-328.

31. Berger SL. The complex language of chromatin regulation during transcription. Nature. 2007; 447:407-412.

32. Ruan Q, Kameswaran V, Zhang Y, Zheng S, Sun J, Wang J, DeVirgiliis J, Liou HC, Beg AA, Chen YH. The Th17 immune response is controlled by the Rel-RORgammaRORgamma T transcriptional axis. J Exp Med. 2011; 208:2321-2333.

33. Barnes PJ, Adcock IM, Ito K. Histone acetylation and deacetylation: importance in inflammatory lung diseases. Eur Respir J. 2005; 25:552-563.
34. van den Berg WB, Miossec P. IL-17 as a future therapeutic target for rheumatoid arthritis. Nat Rev Rheumatol. 2009; 5:549-553.

35. Rubbert-Roth A. Assessing the safety of biologic agents in patients with rheumatoid arthritis. Rheumatology (Oxford). 2012; 51 Suppl 5:v38-47.

36. Okada S, Markle JG, Deenick EK, Mele F, Averbuch D, Lagos M, Alzahrani M, Al-Muhsen S, Halwani R, Ma CS, Wong N, Soudais C, Henderson LA, et al. IMMUNODEFICIENCIES. Impairment of immunity to Candida and Mycobacterium in humans with bi-allelic RORC mutations. Science. 2015; 349:606-613.

37. Bandaru A, Devalraju KP, Paidipally $P$, Dhiman R, Venkatasubramanian S, Barnes PF, Vankayalapati R, Valluri V. Phosphorylated STAT3 and PD-1 regulate IL-17 production and IL-23 receptor expression in Mycobacterium tuberculosis infection. Eur J Immunol. 2014; 44:2013-2024.

38. O'Kane CM, Elkington PT, Jones MD, Caviedes L, Tovar M, Gilman RH, Stamp G, Friedland JS. STAT3, p38 MAPK, and NF-kappaB drive unopposed monocyte-dependent fibroblast MMP-1 secretion in tuberculosis. Am J Respir Cell Mol Biol. 2010; 43:465-474.

39. North Chicago I. USA: Abbott Laboratories; 2009. Humira (adalimumab) injection, solution [prescribing information].

40. Sanmarti R, Inciarte-Mundo J, Estrada-Alarcon $P$, Garcia-Manrique M, Narvaez J, Rodriguez-Moreno J, Gomez-Centeno A, Pascal M, Yague J. Towards optimal cut-off trough levels of adalimumab and etanercept for a good therapeutic response in rheumatoid arthritis. Results of the INMUNOREMAR study. Ann Rheum Dis. 2015; 74:e42.

41. Chen DY, Chen YM, Tsai WC, Tseng JC, Chen YH, Hsieh CW, Hung WT, Lan JL. Significant associations of antidrug antibody levels with serum drug trough levels and therapeutic response of adalimumab and etanercept treatment in rheumatoid arthritis. Ann Rheum Dis. 2015; 74:e16.

42. Hung CH, Yang SN, Kuo PL, Chu YT, Chang HW, Wei WJ, Huang SK, Jong YJ. Modulation of cytokine expression in human myeloid dendritic cells by environmental endocrinedisrupting chemicals involves epigenetic regulation. Environ Health Perspect. 2010; 118:67-72.

43. Ratajewski M, Walczak-Drzewiecka A, Salkowska A, Dastych J. Upstream stimulating factors regulate the expression of RORgammaT in human lymphocytes. J Immunol. 2012; 189:3034-3042. 